\title{
Spatial and temporal vegetation analysis of Amberley Wild Brooks over two decades
}

\author{
D. Hicks, F. Abraham, L. Bardsley*, M. Cousins, E. Webster \& J. Whitman. \\ Natural England, Worthing, UK BN11 1LD
}

*Corresponding author: Louise Bardsley louise.bardsley@naturalengland.org.uk

This pdf constitutes the Version of Record published on $14^{\text {th }}$ December 2019

\begin{abstract}
Plant species presence data from 170 ditches at Amberley Wild Brooks in 2017 were compared to those of 1998 . Overall functional changes are apparent, and spatial interpolation by Inverse Distance Weighting suggests that areas of the site are exhibiting varying character in space and time. Vegetation traits suggest a response to drier, more saline and more open conditions since 1998. Stress-tolerating species now dominate ruderals and competitors, and the site supports a similar number of hydrophytes and a greater number of species overall. Site-wide nutrient input was not observed in either Ellenberg N or LEAFPACS2 metrics although there are local patterns which warrant investigation. Using these data there appears to have been no decrease in overall presence of the rare and scarce species of the 1998 survey except Sium latifolium $\mathrm{L}$. In terms of plant climatic optima the site has shifted southwards, to warmer and drier conditions, which correlates to the change in 25year averages of climate to 1998 and to 2017 at the closest Met Office weather station. These patterns are applicable to site management and flood risk management proposals, giving potential for spatial modelling to predict outcomes under different management scenarios.
\end{abstract}

\section{Keywords}

spatial interpolation; flood plain; wetland; aquatic; plant community; climate change

\section{Introduction}

Occurring naturally in every continent, wetlands are characterised by vegetation that is adapted to its saturated and frequently anoxic substrate. These systems perform stabilising ecological functions at the transition between land and water, though are subject to pressures from drainage, eutrophication and invasive species.

Amberley Wild Brooks is a managed wetland in the flood plain of the River Arun, north of the village of Amberley and within the South Downs National Park. Along with other sections of the Arun Valley it is designated as a Special Area of Conservation (SAC), Site of Special Scientific Interest (SSSI), Important Plant Area (IPA), Special Protection Area (SPA), Important Bird Area (IBA), and Ramsar site. Over half of all the British species of aquatic plants are represented here, as well as many rare invertebrates and nationally significant wintering and breeding wildfowl.

The site is an extensive area of grazing marsh dissected by drainage ditches. Historically the banks of the rivers have been raised and sluices installed in the ditches to speed drainage of water during winter floods, indeed tithe ditches and 
maps (WSRO, 1532-1929) going back to the $17^{\text {th }}$ century show much the same pattern of ditches as now. In summer, feeder ditches carry water from chalk springs nearby and underground water percolates through the peat. There is a small area of derelict raised bog in part of the site which indicates that historically the wetland may have been very different in character before extensive drainage. The northern half of the site is largely in conservation ownership and management and the southern half of the site is used for grazing and silage production.

The river flows along the western boundary of the SSSI (Fig. 1), passing through farmland and downstream through well-populated areas that have been considerably affected by flooding in recent years. Here it is tidally influenced, with corresponding management to reduce spate damage to land and property by flooding. Embankments are currently managed under permissive powers to maintain and improve main river watercourses. Water level and ditch management at Amberley Wild Brooks is managed in accordance with the Water Level Management Plan for the SSSI which was implemented in 2006 (Environment Agency, 2006).

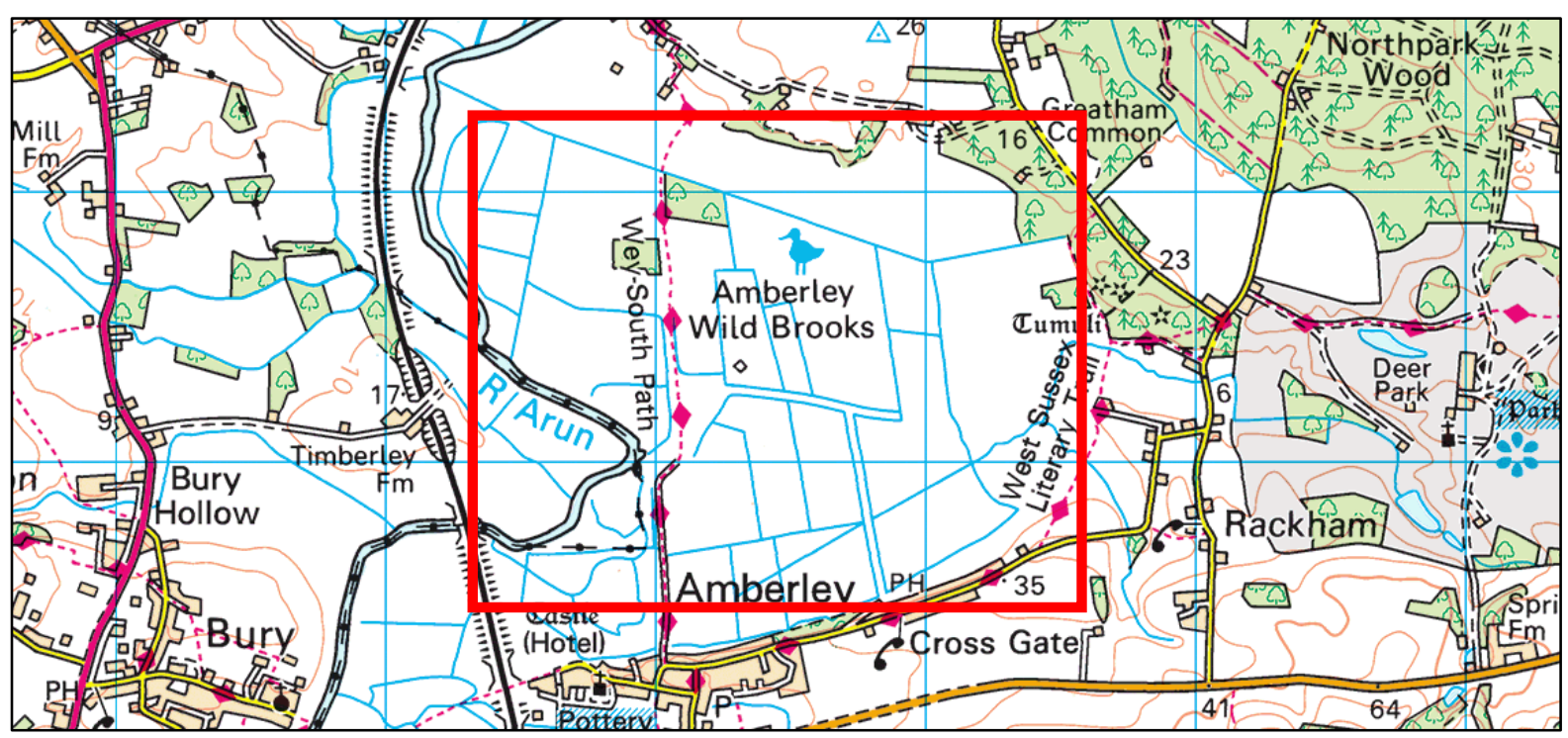

Figure 1. Ordnance Survey base map of Amberley Wild Brooks (OS Open Data, 2018). 1 grid line = 1km; red lines mark the bounding box of the IDW rasters of Figures 3 to 7 .

\section{Methods}

Field survey

The site was systematically surveyed by dividing into homogeneous groups of ditches, subdividing those which were over approximately 400 metres in length, and excluding those which were dry or heavily shaded.

The bankful (i.e. the wetted area in the channel under all but flooding conditions) length of each ditch was walked between late July to early August and all vascular plants, the liverwort Riccia fluitans $\mathrm{L}$., charophytes and filamentous algae were recorded as present or absent. A grapnel was used at intervals to sample submerged vegetation. 


\section{Data preparation}

Harmonisation of taxonomic lists between different survey teams and years was done by merging synonyms to the most recent published name, any record of 'cf' taken to genus only, and taxa which were differentially recorded (i.e. to species at one site and to genus at another) globally aggregated to genus. It is assumed that field teams did not systematically survey different micro-habitats of the ditch, and that any year-specific differences of weather or management did not impact upon the surveyable area.

For repeat-surveyed ditches the plots were matched to pairs, and any nonmatched surveys ( $n=22$ ditches) were removed for this analysis. Where several surveys were carried out in both 2016 and 2017 ( $n=29$ ditches) the single most complete of these was used. For convenience from this point onwards the 'baseline' and 'present' time points are labelled 1998 and 2017. The result was a total of 170 ditches represented by paired surveys for each year (see supplementary material, 'dataframe 6.csv').

\section{Description of the variables}

The survey data for each ditch at each year were reduced to a set of vegetation indices conventionally used to compare different sites or time points:

\section{a.) Taxonomic richness}

Two definitions were used here to produce figures per ditch, using species designations at the time of the baseline survey (Abraham, 1998): i. total number of species, and ii. number of Red Data Book and Nationally Scarce species (hereafter abbreviated respectively to 'rare' and 'scarce' species).

b.) LEAFPACS2 river water quality metrics

One of the tools produced for the UK Water Framework, LEAFPACS2 (Willby et al., 2009) Directive is a model of the data from a large set of UK river macrophyte surveys. For the Amberley analysis we consider two of its metrics:

The river macrophyte nutrient index (RMNI) represents the mean of the 170 per ditch RMNI scores of the taxa recorded in the field survey.

The number of macrophyte taxa (NTAXA) is a diversity metric comprising a count of the number of scoring taxa recorded in the field survey. For this, only taxa which are considered truly aquatic, i.e. hydrophytes, are included in the counts and means thereof.

\section{c.) Plant climatic optima}

The average for all plant species per ditch was calculated using the plant climatic values of Hill et al. (2004). Those values are the mean climate (i.e. Tjan = mean January temperature, Tjul $=$ mean July temperature, Prec $=$ mean annual precipitation) of the $10-\mathrm{km}$ squares where they occur in Britain, Ireland and the Channel Islands.

\section{d.) Ellenberg plant traits}

Ellenberg et al. (1991) defined seven major scales to summarise plant species niches, five of which were used in this analysis for each ditch - light $(L)$, moisture $(F)$, reactivity, which is an index of acidity $(R)$, fertility $(N)$ and salinity $(S)$. ' $L$ ' 
ranges from 1 (deep shade) to 9 (full light), ' $F$ ' ranges from 1 (extreme dryness) to 12 (submerged plant), ' $R$ ' ranges from 1 (extreme acidity) to 9 (basic), ' $N$ ' ranges from 1 (infertile substrate) to 9 (rich substrate), and ' $S$ ' ranges from 0 (absent from saline sites) to 9 (extreme saline conditions). Hill et al. (2004) was used to obtain these plant niche values for the species present at Amberley.

\section{e.) Grime plant strategies}

Grime (1979)'s competitor (C), stress-tolerator (S) and ruderal (R) species values were calculated as means for each ditch, again using Hill et al. (2004) to obtain the individual plant species values.

Grime's model classifies British vegetation in terms of the three established strategies, which were originally used to plot as a coordinate in a triangle whose points are C, S and R. Here we use them as three separate indices, whilst recognising that they are not independent: for any site an average increase in one will lead to an average decrease in one or other strategy.

\section{Analysis of vegetation indices}

Vegetation indices were calculated for the resulting matrix of 340 surveys and 198 taxa using the per species values of Hill et al. (2004), and LEAFPACS2 indices were calculated from the UK TAG survey metric calculator (Willby, 2015).

All statistics and graphical illustrations were produced in R (R core team, 2017), specifically the packages ggplot2, car, rgdal, raster, ggmap, gstat and xts. Amberley basemaps were downloaded from GoogleEarth (2018) satellite imagery and Ordnance Survey (2018) data.

The interpolation maps were generated by Inverse Distance Weighting (IDW) on a grid of 10000 cells, with squared weights calculated using the Shepard (1968) method. IDW extrapolates values to unknown points using the values available at the known points $(n=170)$; this method was recently found to outperform others on hydrological data in terms of median absolute error (Cheng et al. 2017).

Distributional assumptions (normality, equal variance) of the plant indices were checked prior to performing paired significance tests. All raw data and R scripts are available on request.

\section{Results}

Non-parametric hypothesis tests (Wilcoxon, 1945) were used to test for differences between the vegetation indices at baseline in 1998 and resurvey in 2017 (Table 1).

Overall at Amberley Wild Brooks from 1998 to 2017 the number of rare and scarce species per ditch appears to have increased by a mean of 0.3 species. Total species richness has increased by a mean of nearly 4 species. The latter is considered more vulnerable to surveyor differences, as some people find more or less species than others. It is assumed here that surveyors' records are a true representation of their presence and absence.

The fact that the number of strictly aquatic species (NTAXA) has not significantly changed suggests either that surveyors in 2017 have tended to record more species growing further up the bank of the ditch, or that there has been a real shift towards more terrestrial species at Amberley Wild Brooks. The latter is supported by the fact that both Ellenberg $\mathrm{F}$ (moisture) has decreased (on average 
by 0.12 points on its scale of 1 to 12 ) and that Grime Stress-tolerant has increased (on average by 0.09 points on its scale from 0 to 4 ).

Table 1. Hypothesis tests of the vegetation variables for Amberley Wild Brooks at baseline $(n=170)$ and resurvey $(n=170)$

\begin{tabular}{|c|c|c|c|c|}
\hline & \multicolumn{4}{|c|}{ paired Wilcoxon test } \\
\hline & $\mathbf{v}$ & $\mathbf{p}$ & $\begin{array}{c}\text { mean } \\
\text { difference }\end{array}$ & $\begin{array}{c}\text { effect } \\
\text { size }\end{array}$ \\
\hline total species & 4514.5 & 0.000 & 3.77 & $\begin{array}{c}3.8 \\
\text { species }\end{array}$ \\
\hline $\begin{array}{c}\text { total rare/scarce } \\
\text { species }\end{array}$ & 1947.0 & 0.000 & 0.29 & $\begin{array}{c}0.3 \\
\text { species }\end{array}$ \\
\hline RMNI & 7709.0 & 0.493 & -0.03 & - \\
\hline NTAXA & 6429.5 & 0.257 & -0.42 & - \\
\hline Tjan & 5399.0 & 0.004 & 0.01 & $0.01^{\circ} \mathrm{C}$ \\
\hline Tjul & 5509.0 & 0.022 & 0.02 & $0.02{ }^{\circ} \mathrm{C}$ \\
\hline Prec & 8176.5 & 0.158 & -2.60 & - \\
\hline Ellenberg L & 4062.0 & 0.000 & 0.03 & $0.4 \%$ \\
\hline Ellenberg F & 9050.0 & 0.006 & -0.12 & $-1 \%$ \\
\hline Ellenberg $\mathbf{R}$ & 7791.0 & 0.125 & -0.02 & - \\
\hline Ellenberg $\mathbf{N}$ & 8236.0 & 0.098 & -0.05 & - \\
\hline Ellenberg S & 1200.5 & 0.000 & 0.12 & $1.3 \%$ \\
\hline Grime Competitor & 9504.5 & 0.000 & -0.11 & $-3 \%$ \\
\hline $\begin{array}{l}\text { Grime Stress- } \\
\text { tolerant }\end{array}$ & 4571.0 & 0.000 & 0.09 & $2 \%$ \\
\hline Grime Ruderal & 8373.0 & 0.002 & -0.06 & $-1.4 \%$ \\
\hline
\end{tabular}

If Bonferroni correction (Bonferroni, 1936) is applied to control for the multiple comparisons, this conservative adjustment would make Tjul insignificant and Ellenberg $\mathrm{F}$ borderline significant. That no significant change is apparent in either RMNI or Ellenberg $\mathrm{N}$ implies that there is no evidence for increased or decreased eutrophication at Amberley Wild Brooks across the site as a whole during this period.

A small increase in Ellenberg $L$, together with the changes in Grime plant strategy values, suggests that there has been a functional change in the plant 
community at Amberley Wild Brooks. The implication is of a shift to a sparser, more open vegetation, in a habitat which favours species adapted to biological stress, which could include disturbance such as ditch cleaning.

The plant climatic means of Tjan, Tjul and Prec were compared to the actual climate data of the closest representative Met Office weather station (Eastbourne, where the average of the preceding 25 years was calculated for 1998 and for 2017) (Table 2). Whilst the magnitude of Tjan, Tjul and Prec do not match the magnitude of the actual climate averages, and the apparent difference is small, their direction of change is consistent towards warmer and drier conditions.

Total plant species richness (size of circle) and number of Red Data Book or Nationally Scarce plant species (increasing from dark blue to pale blue) for each ditch is illustrated on a GoogleEarth (2018) satellite basemap (Fig. 2).

Table 2. Long term climatic means at Eastbourne meteorological station (Met Office, 2018) compared to vegetation climatic optima for Amberley Wild Brooks at baseline $(n=170)$ and resurvey $(n=170)$

\begin{tabular}{|c|c|c|c|}
\cline { 2 - 4 } \multicolumn{1}{c|}{} & $\mathbf{1 9 9 8}$ & $\mathbf{2 0 1 7}$ & difference \\
\hline $\begin{array}{c}\text { 25-year mean monthly temp } \\
\text { January, }^{\circ} \mathbf{C}\end{array}$ & 5.614 & 6.222 & 0.608 \\
mean Tjan & 3.659 & 3.667 & 0.008 \\
\hline $\begin{array}{c}\text { 25-year mean monthly temp } \\
\text { July, }^{\circ} \mathbf{C}\end{array}$ & 17.184 & 17.736 & 0.552 \\
\hline $\begin{array}{c}\text { mean Tjul } \\
\text { 25-year mean annual rainfall, } \\
\text { mm }\end{array}$ & 14.960 & 14.980 & 0.020 \\
\hline \begin{tabular}{c} 
mean Prec \\
\hline
\end{tabular} & 977.573 & 777.250 & -0.323 \\
\hline
\end{tabular}

Clustering of rare and scarce species is evident, particularly in the northern half of the site, which was in conservation ownership and management for most of the period and also has the largest diversity of hydrogeological conditions. There have been localised gains and losses across the period.

Any changes in abundances will not have been directly captured by these presence-only datasets, but overall (Table 3 ) there appears to have been an increase in the presence of Potamogeton acutifolius Link, Leersia oryzoides (L.) Sw., Carex vulpina L. (but note that this was not specifically searched for in 1998) and Potamogeton trichoides Cham. \& Schltdl., and a decrease in Sium latifolium L. and Wolffia arrhiza (L.) Horkel ex Wimm. (to zero in the matched data, although this species was recorded once in the 2016/2017 surveys). 


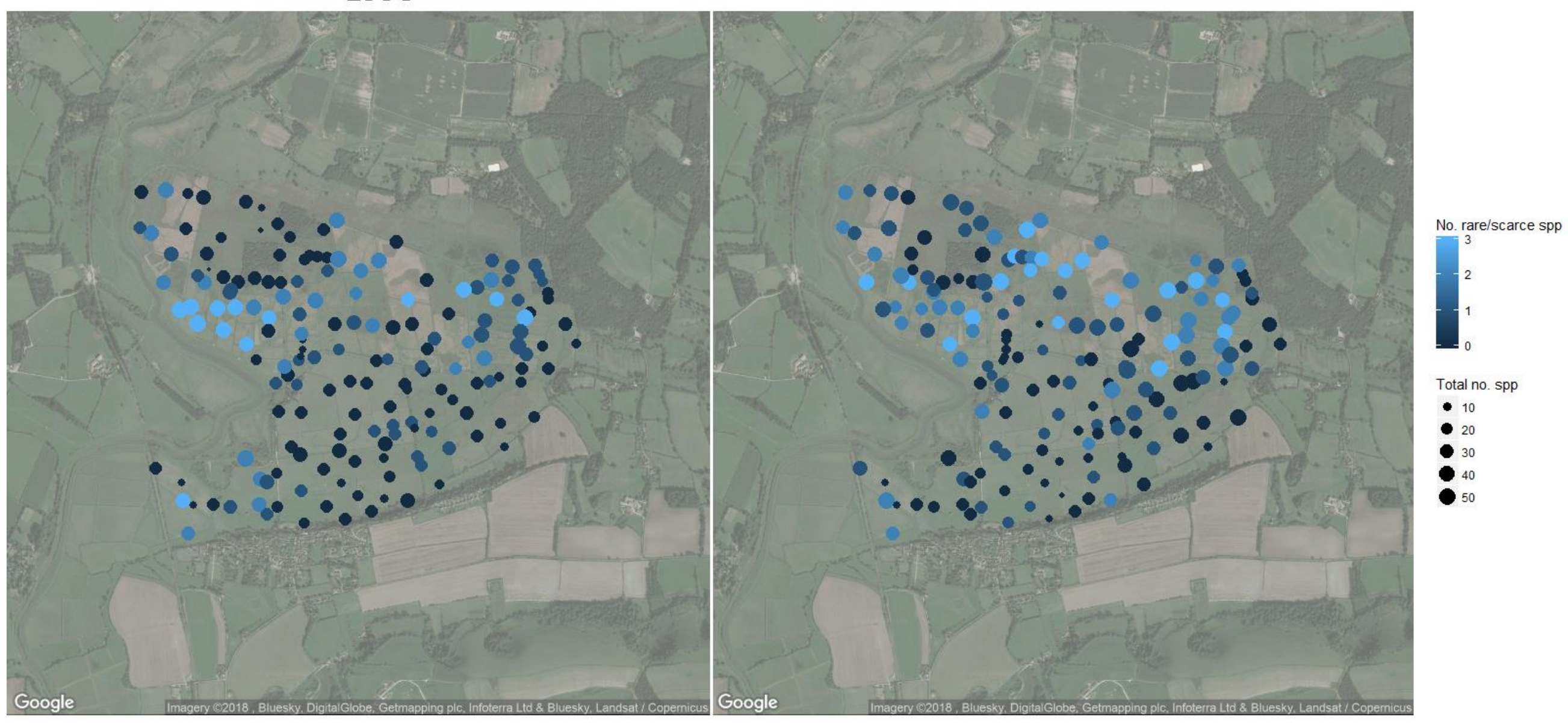

Figure 2. Total plant species richness (size of circle) and number of Red Data Book or Nationally Scarce plant species (increasing from dark blue to pale blue) at Amberley Wild Brooks at baseline $(n=170)$ and resurvey $(n=170)$ overlaid on GoogleEarth (2018) satellite basemap. 
Table 3. Presence of designated plant species among the $(n=170)$ matched ditches of Amberley Wild Brooks at baseline and resurvey.

\begin{tabular}{|c|c|c|c|}
\hline \multirow[b]{2}{*}{ species } & \multirow[b]{2}{*}{ status } & \multicolumn{2}{|c|}{$\begin{array}{l}\text { number of ditches } \\
\text { recorded present (of the } \\
170 \text { matched) }\end{array}$} \\
\hline & & 1998 & 2017 \\
\hline $\begin{array}{c}\text { Potamogeton } \\
\text { acutifolius }\end{array}$ & Red Data Book & 67 & 87 \\
\hline Leersia oryzoides & Red Data Book & 29 & 47 \\
\hline Carex vulpina & Red Data Book & 0 & 3 \\
\hline Sium latifolium & $\begin{array}{l}\text { Nationally } \\
\text { Scarce }\end{array}$ & 7 & 3 \\
\hline $\begin{array}{c}\text { Potamogeton } \\
\text { trichoides }\end{array}$ & $\begin{array}{l}\text { Nationally } \\
\text { Scarce }\end{array}$ & 24 & 35 \\
\hline Wolffia arrhiza & $\begin{array}{l}\text { Nationally } \\
\text { Scarce }\end{array}$ & 1 & 0 \\
\hline
\end{tabular}


IDW raster of LEAFPACS RMNI at Amberley 1998

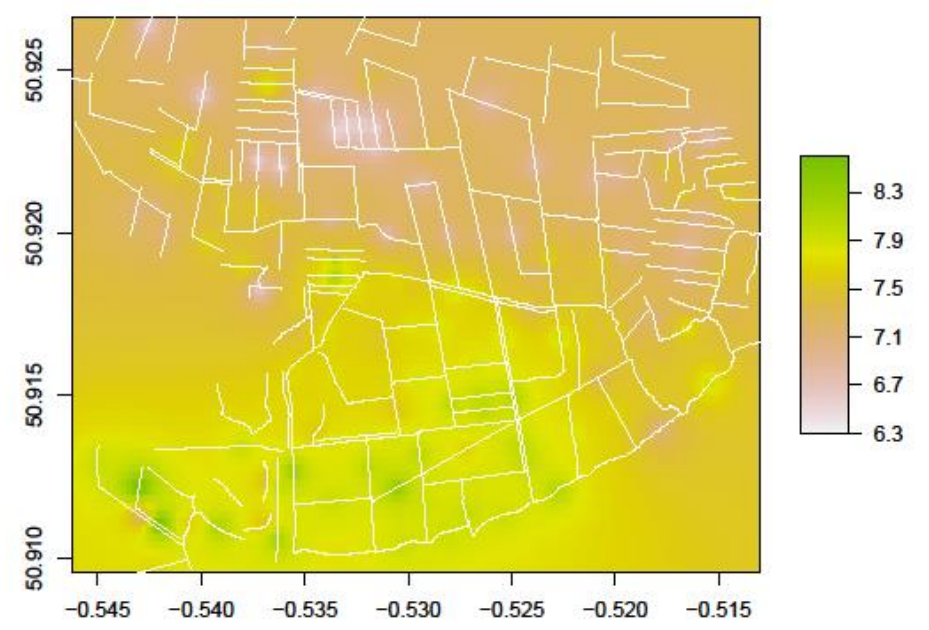

IDW raster of LEAFPACS RMNI at Amberley 2017

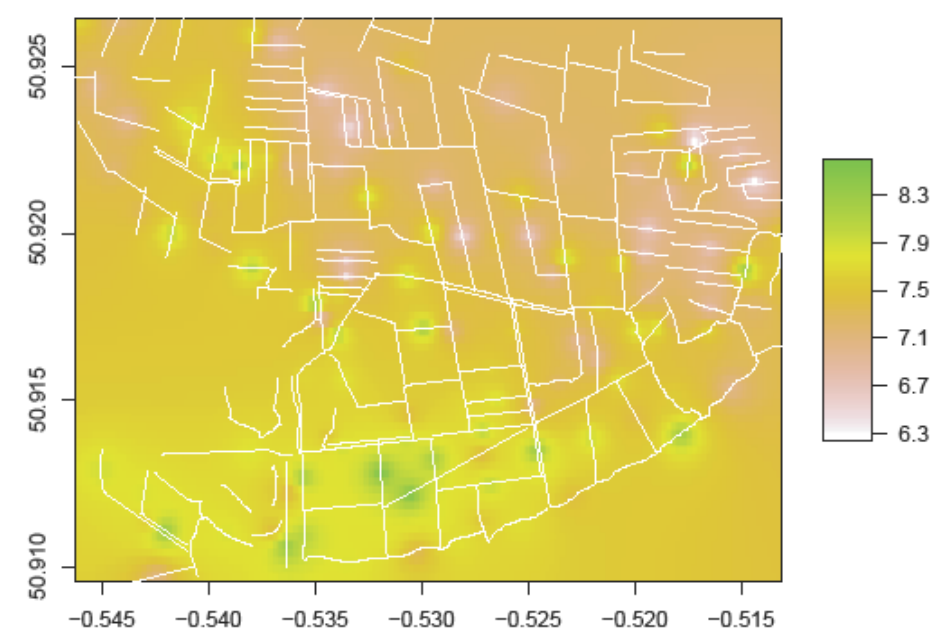

Figure 3. IDW interpolation map of LEAFPACS2 RMNI values at Amberley Wild Brooks at baseline and resurvey (scale markers are latitude and longitude)

While the Wilcoxon test did not report a significant change overall of RMNI, some localised increase in nutrient input is suggested by the elevated RMNI of the northern (particularly the northwestern) half of the site in 2017 (Fig. 3). 



Figure 4. IDW interpolation map of Ellenberg light values at Amberley Wild Brooks at baseline and resurvey (scale markers are latitude and longitude)

There is an indication that the overall significant change to more open plant-growing conditions has been more marked in the north and east of the site (Fig. 4). 

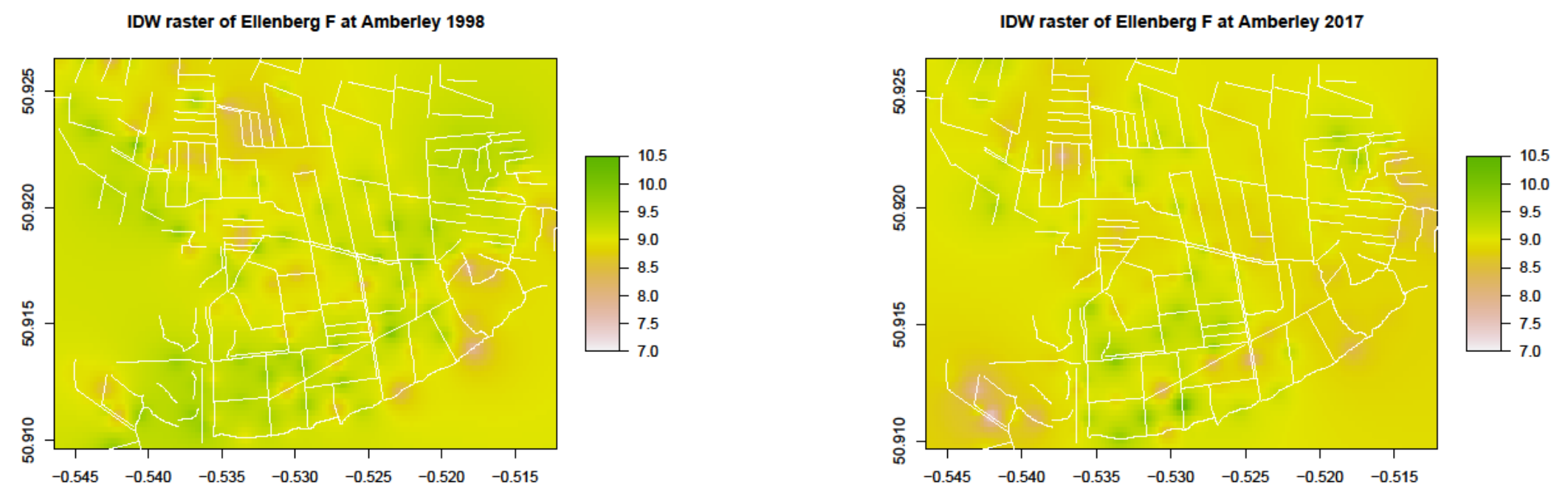

Figure 5. IDW interpolation map of Ellenberg moisture values at Amberley Wild Brooks at baseline and resurvey (scale markers are latitude and longitude).

The overall decrease in this plant indicator of moisture is evident across much of the site (Fig. 5). 

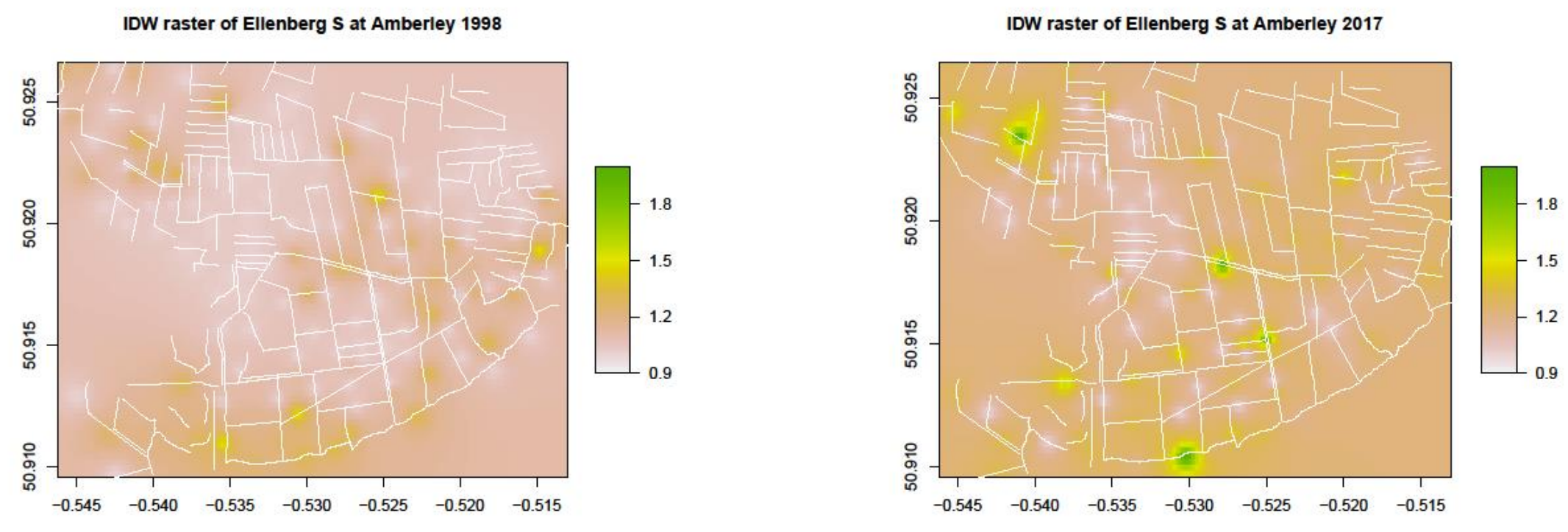

Figure 6. IDW interpolation map of Ellenberg salinity values at Amberley Wild Brooks at baseline and resurvey (scale markers are latitude and longitude)

The overall significant increase in this plant indicator of more saline conditions appears to have been localised in several ditches in the western half of the site (Fig. 6). 
IDW raster of Grime Stress Tolerant at Amberley 1998

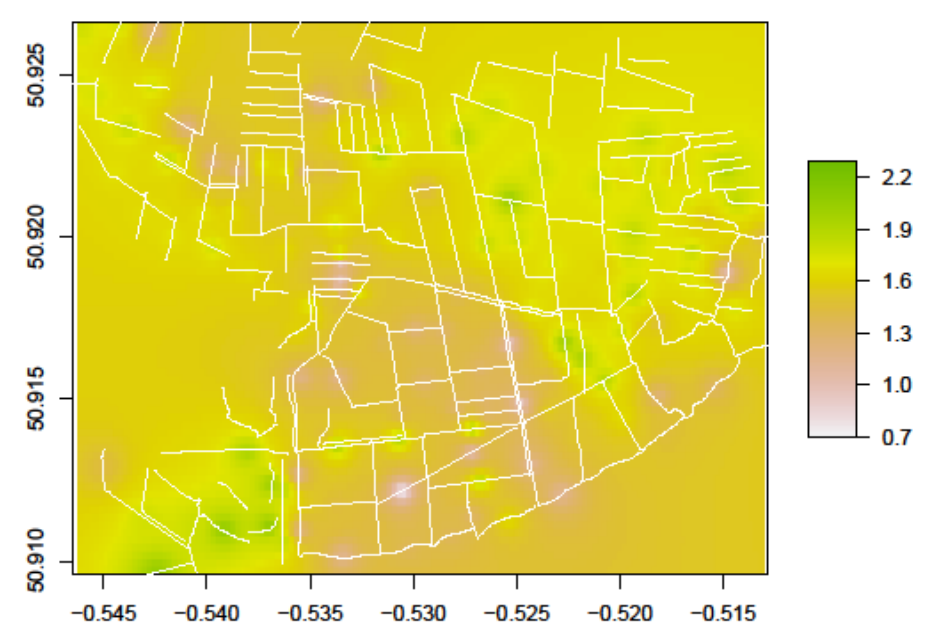

IDW raster of Grime Stress Tolerant at Amberley 2017

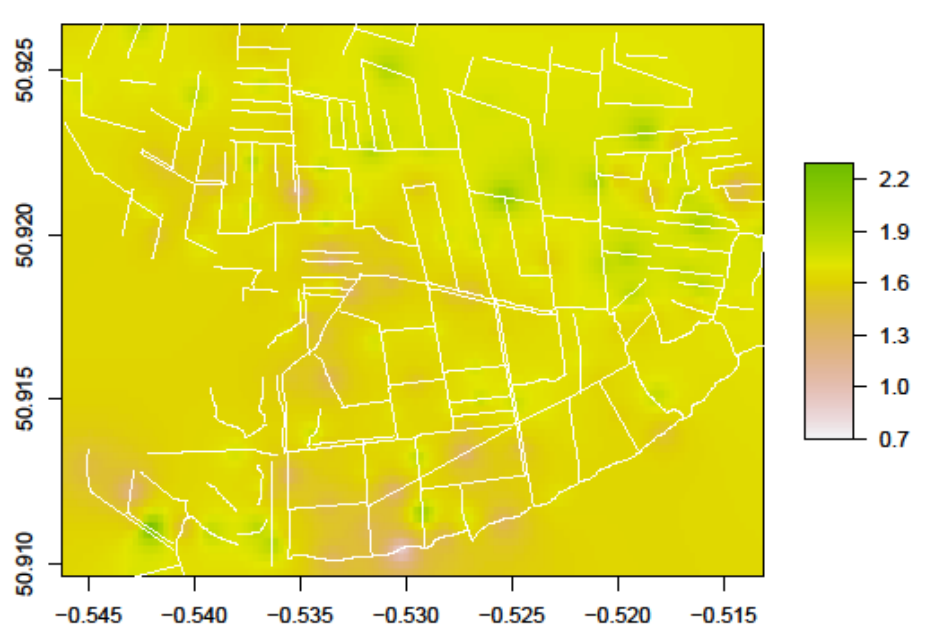

Figure 7. IDW interpolation map of Grime Stress-tolerant values at Amberley Wild Brooks at baseline and resurvey (scale markers are latitude and longitude)

The overall significant increase in conditions favourable to stress-tolerant plants is marked in the northwest and southeast of the site (Fig. 7). 


\section{Discussion}

Table 1 presents compelling evidence that there have been functional changes in the vegetation community of Amberley Wild Brooks from 1998 to 2017, in particular towards plants which favour a more open, drier and more saline habitat. Stresstolerating species now dominate ruderals and competitors, and the site supports a similar number of hydrophytes and a slightly increased species richness overall.

In line with other analyses of plant trait values (Bartelheimer \& Poschlod 2015; Smart \& Scott 2004; Schaffers \& Sykora 2000) we interpret plant indices to be robust to surveyor effort when averaged to the scale of ditch vegetation. The assertion is that any differential finding (addition or omission) of a few species is unlikely to have a large effect on the overall weighted mean, and in the case of Ellenberg or Grime values the differential species are likely to be of similar index value. Indeed a similar two-decade study (Woodcock et al. 2011) concluded that functional traits of grassland vegetation could be used to test the success of EU agrienvironment policy interventions, which in the current UK political climate suggests demand for this method.

\section{Site management}

The significant overall differences, for instance of Ellenberg moisture and Ellenberg salinity, at Amberley Wild Brooks between 1998 and 2017 may be of particular relevance both to habitat management of the site and to flood risk intervention within the wider Arun Valley. The largest abstraction for public water supply in the greensand aquifer near here is near the confluence of the Arun and its main tributary the Rother, and though the abstraction impacts do travel under the river they are not believed to impact Amberley due to the Greenhurst anticline in the geology of the greensand. Further investigation is being sought to confirm this. Likewise the marked increase in mean Ellenberg light in the northeast section of the site (Fig. 4) may reflect that this area was bought into conservation ownership part way through the period. We suggest that management at ditch level is likely to be pivotal to the plant and animal species for which the site is designated. It seems likely also that some adverse outcomes across the two decades could be attributed to alterations in management, including overall under-grazing and the recent reduction of early-season grazing, and there may be highly localised effects (e.g. reduction of the open mud habitat along ditch margins, shading and/or coarsening of marginal vegetation) which are not detected by the spatial resolution of these surveys.

The future management of the river valley in which Amberley sits is under discussion. At present the river embankments along Amberley Wild Brooks largely prevent the saline tidal waters from entering this freshwater site. The embankments, which currently run all the way down the valley to the coast, push the saline wedge higher up the river valley than a more naturally functioning estuarine system, an effect which would be expected to exacerbate under climate change.

\section{Scenario modelling}

It will be possible to build on the work in this paper to model predicted botanical changes under different scenarios of future climate change and flood defence bank management as outlined by Wheeler et al. (2004). Elsewhere Lang et al. (2014) concluded that with effective restoration in a floodplain, turning overall conditions 
wetter, Ellenberg values of its vegetation will respond in a useful way for monitoring. Translated to a single faunal species for example, ecological studies of one of the rare molluscs of Amberley Wild Brooks, Anisus vorticulus (e.g. JNCC 2007; Watson \& Ormerod 2004) describe the main threats of land drainage, inappropriate habitat management and eutrophication.

Using two measures of plant response (Ellenberg $\mathrm{N}$ and LEAFPACS2) we have found no statistically significant increase in nutrient-demanding species at Amberley Wild Brooks as a whole, though there appear to have been localised differences (Fig. 3 ). Given that the overall nutrient status of the substrate is often found to be the major axis of vegetation community change (e.g. McCollin \& Geraghty, 2015; Pallett et al., 2016), this underlines the importance of the drivers of light, moisture and salinity mentioned above. These apparent environmental determinants could be corroborated by physiochemical monitoring of a sample of ditches across the year, as such measures of biological response may be unperturbed by acute and temporary changes in water quality. Midsummer would be a pertinent time to monitor for any ingress of poor quality water from the heavily modified River Arun.

\section{Species locations}

There is a suggestion that the nationally scarce species Sium latifolium (and more tenuously, Wolffia arrhiza) have decreased in presence over this 20 year period, but the pattern for the three Red Data Book species (as designated in 1998) is one of increase in presence. Note however that Carex vulpina was not specifically searched for in the 1998 survey as was deemed to be over at this point of the season (August).

It is important to reiterate that the nature of this dataset is presence-only rather than abundance, so changes in number of individuals of these species may have taken a different trajectory. In addition we have not been able to examine individual taxa which are rare or local in Sussex, e.g. Baldellia ranunculoides (L.) Parl., Utricularia australis R. Br. (both recorded in 1998 but not in 2017), Persicaria minor (Huds.) Opiz (recorded in 23 ditches in 1998 and 26 ditches in 2017) and charophytes (recorded in 11 ditches in 1998 and 4 ditches in 2017).

Given the conservation status of these species it would be advisable in any future surveys to record abundance as well. In addition several visits would be required in order to account for their differing peak-seasonality.

\section{Species shifts}

The apparent west-to-north shift in location of hotspots of rare or scarce species (Fig. 2) may be correlated to habitat management changes over this period and therefore inform conservation management. With further ground-truthing it may be possible to correlate this to Fig. 4, to infer that the change in hotspots are related to the localised shifts to more open conditions, for example as a result of ditch management.

Given that plant species distributions are not of homogenous sizes, nor uniformly represented within their range, we might only expect mean plant climatic optima to correlate to actual climate in the middle latitudes of the Britain, Ireland and the Channel Islands. Furthermore, a large change in this index would not be expected given that a) there has not been a large change in actual climate over this 
period, and b) that even with species replacement these averaged plant indices are hard to shift from central values.

The consistent and unidirectional shift in mean climatic optima of the Amberley Wild Brooks plant community is intriguing. A suitable test of the robustness of this response would be to replicate the same analysis on other UK sites over similar time periods, with control for any differing land management in a mixed effects model.

\section{Acknowledgements}

Many thanks to Haney King for data provision and preparation and to Sam Dixon for constructive feedback on the analyses.

\section{References}

Abraham, F. 1998. Amberley Wild Brooks: A survey of the ditch flora 1998. Arun District Council.

Bivand, R., Keitt, T. \& Rowlingson, B. 2019. rgdal: Bindings for the 'Geospatial' Data Abstraction Library. R package version 1.4-4. https://CRAN.Rproject.org/package $=$ rgdal

Bartelheimer, and Poschlod, P. 2015. Functional characterizations of Ellenberg indicator values - a review on ecophysiological determinants. Functional Ecology 30: 506-516. https://besjournals.onlinelibrary.wiley.com/doi/full/10.1111/1365-2435.12531

Bonferroni, C.E. 1936. Teoria statistica delle classi e calcolo delle probabilità, Pubblicazioni del R Istituto Superiore di Scienze Economiche e Commerciali di Firenze.

Cheng, M., Wang, Y., Engel, B., Zhang, W., Peng, H., Chen, X. \& Xia, H. 2017. Performance assessment of spatial interpolation of precipitation for hydrological process simulation in the Three Gorges Basin. Water 9: 838, 1-18. https://www.mdpi.com/2073-4441/9/11/838

Ellenberg, H., Weber, H.E., Düll, R., Wirth, V., Werner, W. \& Paulissen, D. 1991. Zeigerwerte von Pflanzen in Mitteleuropa. Scripta Geobotanica 18: 1-248.

Environment Agency. 2006. Amberley Wild Brooks SSSI water level management plan.

Fox, J., Fox \& Weisberg, S. 2019. An $\{R\}$ Companion to Applied Regression, $3^{\text {rd }}$. ed. Sage: Thousand Oaks CA. https://socialsciences.mcmaster.ca/ifox/Books/Companion/

GoogleEarth Imagery. 20

18. Amberley, UK.

https://www.google.com/maps/place/Amberley,+Arundel/@50.91422295,$0.5429402,4759 \mathrm{~m} / \mathrm{data}=! 3 \mathrm{~m} 1 ! 1 \mathrm{e} 3 ! 4 \mathrm{~m} 5 ! 3 \mathrm{~m} 4 ! 1 \mathrm{~s} 0 \times 4875 \mathrm{ba692dcd085d:0 \times a07d1}$ 88da5330059!8m2!3d50.9063135!4d-0.533755.

Grime, J. P. 1979. Plant strategies and vegetation processes. Chichester: John Wiley. Hijmans, R.J. 2019. raster: Geographic Data Analysis and Modeling. R package version 3.0-2. https://CRAN.R-project.org/package=raster

Hill, M.O., Preston, C.D. \& Roy, D.B. 2004. PLANTATT - Attributes of British and Irish Plants: Status, Size, Life History, Geography and Habitats. NERC Centre for Ecology and Hydrology. http://nora.nerc.ac.uk/id/eprint/9535/ 
Joint Nature Conservation Committee. 2007. Second Report by the UK under Article 17 on the implementation of the Habitats Directive from January 2001 to December 2006. Peterborough: JNCC. http://jncc.defra.gov.uk/pdf/Article17/FCS2007-S2030-Final.pdf

Kahle, D. \& Wickham, H. 2013. ggmap: Spatial Visualization with ggplot2. The $R$ Journal, 5(1): 144-161. http://journal.r-project.org/archive/2013-1/kahlewickham.pdf

Lang, P. \& Ewald, E. 2014. Predictive modelling and monitoring of Ellenberg moisture value validates restoration success in floodplain forests. Applied Vegetation Science 17: 543-555. https://onlinelibrary.wiley.com/doi/abs/10.1111/avsc.12089

McCollin, D. and Geraghty, E. 2015. Change and causes of change in the vascular plant flora of Ireland: 1970-1999. Biology and Environment: Proceedings of the Royal Irish Academy 115B(1): 1-15.

https://www.jstor.org/stable/10.3318/bioe.2015.08?seq=1\#page scan tab co ntents

Met Office Crown Copyright. 2018. https://www.metoffice.gov.uk/public/weather/climate/u100y9uwn.

Ordnance Survey Open Data. 2018. Open Government Licence v3.0. http://www.nationalarchives.gov.uk/doc/open-government-licence/version/3/.

Pallett, D.W., Pescott, O.L. \& Schafer, S.M. 2016. Changes in plant species richness and productivity in response to decreased nitrogen inputs in grassland in southern England. Ecological Indicators 68: 73-81. https://www.sciencedirect.com/science/article/pii/S1470160X15007293

Pebesma, E.J. 2004. Multivariable geostatistics in S: the gstat package. Computers \& Geosciences, 30: 683-691.

R Core Team. 2017. R: A language and environment for statistical computing. Vienna, Austria: R Foundation for Statistical Computing. https://www.R-project.org/

Ryan, J.A. and Ulrich, J.M. 2018. xts: eXtensible Time Series. R package version 0.11-2. https://CRAN.R-project.org/package $=x t s$

Schaffers, A.P. \& Sykora, S.P. 2000. Reliability of Ellenberg indicator values for moisture, nitrogen and soil reaction: a comparison with field measurements. Journal of Vegetation Science 11: 225-244.

https://onlinelibrary.wiley.com/doi/10.2307/3236802

Shepard, D. 1968. A two-dimensional interpolation function for irregularly-spaced data. Proceedings of the 1968 ACM National Conference. 517-524. doi: $10.1145 / 800186.810616$

Smart, S.M. \& Scott, W.A. 2004. Bias in Ellenberg indicator values - problems with detection of the effect of vegetation type. Journal of Vegetation Science 15: 843-846.

http://ukreate.defra.gov.uk/PDFs/Ellenberg\%20indicator\%20values.pdf

Watson, A.M. \& Ormerod, S,J. 2004. The microdistribution of three uncommon freshwater gastropods in the drainage ditches of British grazing marshes. Aquatic Conservation - Marine and Freshwater Ecosystems 14 (3), 221-236. https://onlinelibrary.wiley.com/doi/abs/10.1002/aqc.611

West Sussex Record Office. 1532-1929. Land drainage records of West Sussex. 
Wheeler, B.D., Gowing, D.J.G., Shaw, S.C, Mountford, J.O. \& Money, R.P. 2004. Ecohydrological Guidelines for Lowland Wetland Plant Communities (Eds. A.W. Brooks, P.V. Jose). Environment Agency (Anglian Region). http://www. floodplainmeadows.org.uk/sites/www.floodplainmeadows.org.uk/fil es/files/Eco\%20Hydrological\%20Guidelines\%20(1).pdf

Wickham, H. 2016. ggplot2: Elegant Graphics for Data Analysis. New York: SpringerVerlag.

Willby, N.J., Pitt, J.A. \& Phillips, G. 2009. Development of a system for the classification of lakes and rivers in the UK using aquatic macrophytes. Part II. Rivers. Environment Agency Science Report.

Willby, N.J. 2015. River LEAFPACS2 surveymetriccalculator Sept 2014. Available at: https://www.wfduk.org/sites/default/files/Media/Characterisation\%20of\%20the \%20water\%20environment/Biological\%20Method\%20Statements/River\%20LE AFPACS2\%20surveymetriccalculator\%20Sept2014.xlsx

Wilcoxon, F. 1945. Individual Comparisons by Ranking Methods. Biometrics Bulletin, 1(6): 80-83

Woodcock, B.A., McDonald, A.W. \& Pywell, R.F. 2011. Can long-term floodplain meadow recreation replicate species composition and functional characteristics of target grasslands? Journal of Applied Ecology 48: 1070-1078. https://besjournals.onlinelibrary.wiley.com/doi/full/10.1111/j.13652664.2011.02029.

Copyright retained by author(s). Published by BSBI under the terms of the Creative Commons Attribution 4.0 International Public License.

ISSN: $2632-4970$

https://doi.org/10.33928/bib.2019.01.309 